\title{
Differential effects of hydrographic and biogeochemical properties on the SAR11 clade and Roseobacter RCA cluster in the North Sea
}

\author{
Martin Sperling ${ }^{1,3}$, Helge-Ansgar Giebel ${ }^{1}{ }{\text { Beate } \text { Rink }^{1} \text {, Sebastian Grayek }}^{1}$, \\ Joanna Staneva ${ }^{2}$, Emil Stanev ${ }^{1,2}$, Meinhard Simon ${ }^{1, *}$
}

${ }^{1}$ Institute for Chemistry and Biology of the Marine Environment, University of Oldenburg, 26111 Oldenburg, Germany ${ }^{2}$ Helmholtz Centre for Materials and Coastal Research, 21502 Geesthacht, Germany

${ }^{3}$ Present address: GEOMAR Helmholtz Zentrum für Ozeanforschung, Düsternbrooker Weg 20, 24105 Kiel, Germany

\begin{abstract}
The SAR11 clade and the Roseobacter clade affiliated (RCA) cluster belong to the most prominent bacterioplankton groups in temperate to polar seas. Despite some insights into biological controls of both lineages, little is known about environmental, hydrographic and biogeochemical controls. Therefore, we assessed the abundance of both lineages using quantitative PCR in the southern North Sea, subjected them to a multiple linear regression analysis and related their occurrence to current patterns by backtracking the water masses found at individual stations for the preceding 24 to $27 \mathrm{~d}$. SAR11 constituted $<1$ to $47 \%$ of total bacterial $16 \mathrm{~S}$ rRNA genes. The abundance of this clade was inversely correlated to the salinity change of the water masses at the stations, indicating a preference for stable and presumably nutrient depleted waters. The RCA cluster constituted $<1$ to $5 \%$ of total bacterial $16 \mathrm{~S}$ rRNA genes but did not exhibit any correlation to hydrographic properties. However, a multiple linear regression analysis showed that the RCA cluster was significantly correlated to a suite of biogeochemical parameters, bacterial abundance, concentrations of chlorophyll $a$, particulate organic carbon and suspended particulate matter and salinity changes, explaining $94.3 \%$ of the variability of the RCA data. These results show that backtracking water masses and relating them to bacterioplankton populations aids in the understanding of the growth dynamics of specific bacterioplankton populations and sheds new light on why high abundances of the SAR11 clade are usually found in stratified water masses.
\end{abstract}

KEY WORDS: Hydrography $\cdot$ Bacteria $\cdot$ POC $\cdot$ Chlorophyll $\cdot$ SAR11 $\cdot$ Roseobacter RCA cluster · North Sea

\section{INTRODUCTION}

It is well established that different water masses harbor distinct bacterioplankton communities, even though important players often occur in larger areas, and even throughout oceanic provinces, frequently at varying abundances. This notion is supported by many studies extending over large oceanic areas and across fronts (Baldwin et al. 2005, Pommier et al.
2005, Giebel et al. 2009, Schattenhofer et al. 2009), over more regional zones and mesoscale eddies (Suzuki et al. 2001, Hewson et al. 2006, Alonso-Sáez et al. 2007, Baltar et al. 2007, 2010) and across estuarine salinity gradients (Crump et al. 1999, Selje \& Simon 2003, Hewson \& Fuhrman 2004, Kirchman et al. 2005). These differences in community composition are usually attributed to different environmental conditions, such as general hydrographic features 
(salinity and temperature); however, they are also attributed to the substrate supplied by different phytoplankton communities, the trophic state, grazing and viral infection. Rather little attention has been given to the direct effects of horizontal or vertical current patterns on the spatio-temporal distribution of bacterioplankton communities and populations. Suzuki et al. (2001) found pronounced small scale heterogeneities of the horizontal distribution of major bacterioplankton phylogenetic groups in the Californian upwelling system of the Pacific during an upwelling event. Hewson et al. (2006) studied the relative significance of physical mixing and biological controls of the bacterioplankton community composition in the tropical Atlantic, Gulf of Mexico and the central north Pacific; their results show that the community composition is relatively stable within patch sizes of a few to $\sim 50 \mathrm{~km}$, suggesting that in these open ocean regions physical mixing and biological controls act on different scales in space and time. Baltar et al. (2007) reported pronounced differences in the bacterioplankton community composition along a productivity/upwelling gradient in the northeastern subtropical Atlantic, and Baltar et al. (2010) reported that the composition and activity of prokaryotic communities differ in and outside mesoscale eddies in the northeastern subtropical Atlantic. Studying the seasonal dynamics of the bacterioplankton community in a coastal upwelling system in northwestern Spain, Teira et al. (2008) and AlonsoGutiérrez et al. (2009) found that the SAR11 clade occurred in very low abundances and that the Roseobacter clade greatly dominated Alphaproteobacteria in all seasons. They attributed the low abundance of SAR11 to the upwelling and thus to the hydrography of this dynamic coastal system.

Neritic seas often exhibit complex current patterns that may change seasonally and rapidly according to weather conditions. Even though the general currents may follow consistent and well-established patterns, variations over days and weeks may deviate strongly from these general patterns. Studying the distribution of plankton communities in dynamic coastal systems does not usually take into account the short-term history of the current patterns unless a Lagrangian study design is applied. Hence, to the best of our knowledge, no information is available to clarify whether and how features in plankton dynamics and in the composition and growth of bacterioplankton communities are related to the actual current field or whether the short-term history of water masses is reflected in the bacterioplankton communities or populations.
The German Bight is a shallow region of the southern North Sea with water depths of 10 to $40 \mathrm{~m}$. Current patterns and water masses are highly variable in this shallow sea, even though in general, currents from the southwestern North Sea transport water masses into this area and continue northwards as the Jutland current towards the Skagerrak (Becker et al. 1992, Staneva et al. 2009). To examine whether the short-term history of the water masses and the current field have any effect on the bacterioplankton composition and dynamics, we quantified 2 major lineages of marine Alphaproteobacteria - the SAR11 clade (Rappé et al. 2002) and the Roseobacter RCA cluster (Selje et al. 2004, Giebel et al. 2011) - by quantitative polymerase chain reaction (qPCR) at 10 stations and backtracked the trajectories, temperature and salinity changes of the water masses at these stations for the preceding weeks using the output of a 3-dimensional circulation model developed for the southern North Sea (Staneva et al. 2009). The SAR11 clade is a much wider phylogenetic lineage than the Roseobacter RCA cluster. The former has a sequence similarity of the $16 \mathrm{~S}$ rRNA gene of $>87 \%$, whereas the latter has $>98 \%$ similarity. Both lineages are abundant components of the bacterioplankton in the North Sea (Giebel et al. 2011).

\section{MATERIALS AND METHODS}

\section{Study area and sampling}

Surface water samples were collected on board the RV 'Heincke' with a 101 Niskin bottle at $2 \mathrm{~m}$ depth at 10 locations in the German Bight between 24 and 27 June 2003 (Fig. 1A,B, Table 1). For analysis of suspended particulate matter (SPM), particulate organic carbon (POC) and chlorophyll a (chl a), 500 to $1000 \mathrm{ml}$ of sample water were filtered in duplicates onto precombusted and preweighed glass fiber filters (GF/F, Whatman) and stored at $-20^{\circ} \mathrm{C}$ in the dark until further processing in the lab within $4 \mathrm{wk}$. For enumeration of bacteria, $100 \mathrm{ml}$ of seawater were fixed with formaldehyde $(2 \% \mathrm{v} / \mathrm{v})$ and stored at $4{ }^{\circ} \mathrm{C}$ until further processing within 4 wk. For DNA extraction and PCR analyses, $250 \mathrm{ml}$ of sample water were fractionated by filtration onto polycarbonate filters (Nuclepore) with pore sizes of $5.0 \mu \mathrm{m}$ (particleassociated [PA] bacteria) and subsequently of $0.2 \mu \mathrm{m}$ (free-living [FL] bacteria) and stored at $-20^{\circ} \mathrm{C}$ until further processing. Temperature and salinity were recorded by a built-in probe of the RV 'Heincke' fixed at a depth of $3 \mathrm{~m}$. 

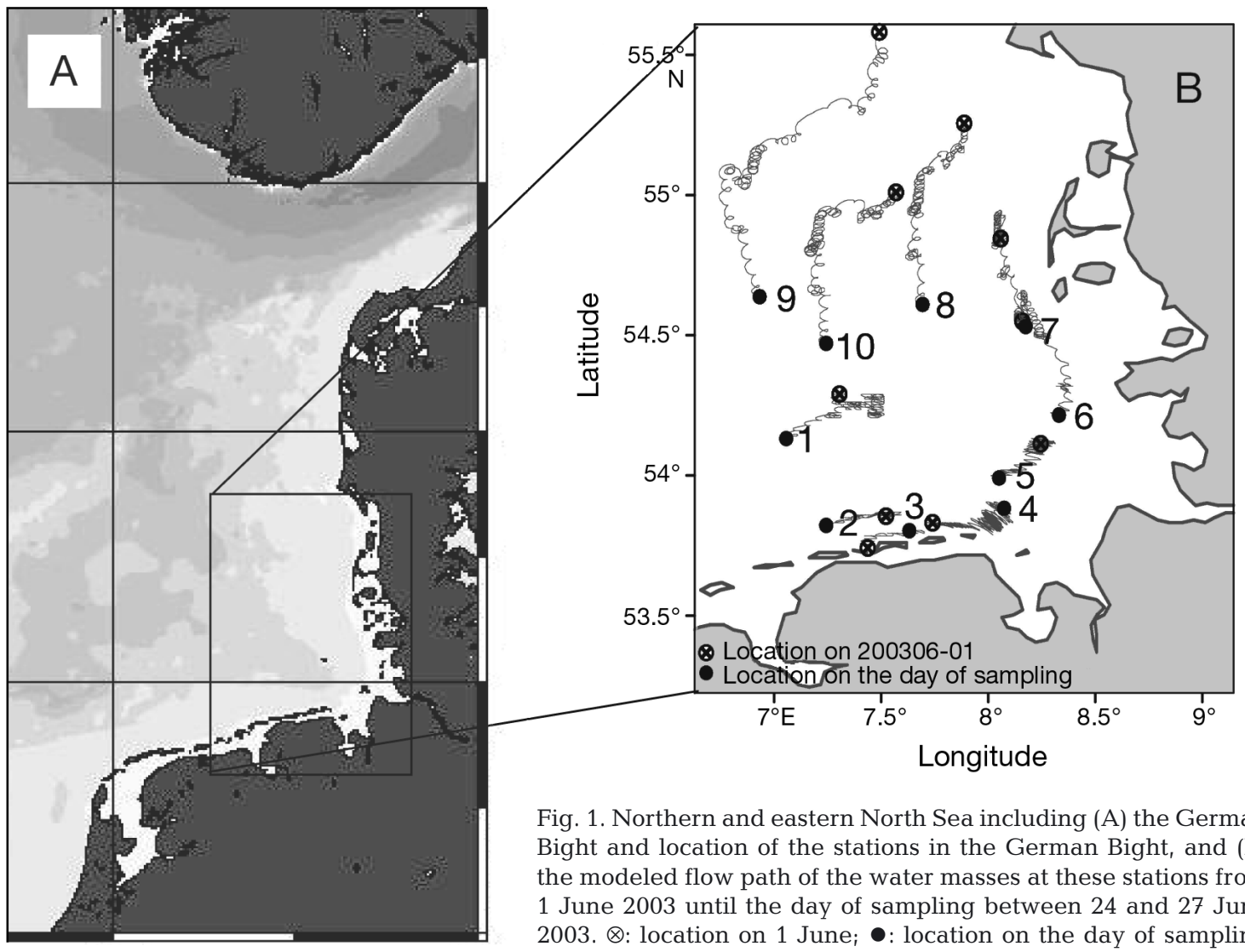

Fig. 1. Northern and eastern North Sea including (A) the German Bight and location of the stations in the German Bight, and (B) the modeled flow path of the water masses at these stations from 1 June 2003 until the day of sampling between 24 and 27 June 2003. $\otimes$ : location on 1 June; $\bullet$ : location on the day of sampling

Table 1. Location of stations, water depth, temperature, salinity and days of sampling

\begin{tabular}{|ccccccc|}
\hline Station & $\begin{array}{c}\text { Latitude } \\
(\mathrm{N})\end{array}$ & $\begin{array}{c}\text { Longitude } \\
(\mathrm{E})\end{array}$ & $\begin{array}{c}\text { Water } \\
\text { depth }(\mathrm{m})\end{array}$ & $\begin{array}{c}\text { Tempera- } \\
\text { ture }\left({ }^{\circ} \mathrm{C}\right)\end{array}$ & $\begin{array}{c}\text { Salinity } \\
\text { Days of sam- } \\
\text { pling 2003 }\end{array}$ \\
\hline 1 & $54^{\circ} 07.98^{\prime}$ & $7^{\circ} 04.64^{\prime}$ & 32 & 15.0 & 35.0 & 26 June \\
2 & $53^{\circ} 49.69^{\prime}$ & $7^{\circ} 15.31^{\prime}$ & 18 & 17.3 & 34.1 & 26 June \\
3 & $53^{\circ} 48.33^{\prime}$ & $7^{\circ} 38.45^{\prime}$ & 8 & 17.4 & 33.5 & 27 June \\
4 & $53^{\circ} 52.95^{\prime}$ & $8^{\circ} 05.24^{\prime}$ & 8 & 17.6 & 33.4 & 24 June \\
5 & $53^{\circ} 59.58^{\prime}$ & $8^{\circ} 03.52^{\prime}$ & 8 & 17.2 & 32.1 & 24 June \\
6 & $54^{\circ} 13.91^{\prime}$ & $8^{\circ} 20.66^{\prime}$ & 11 & 17.1 & 31.8 & 25 June \\
7 & $54^{\circ} 32.08^{\prime}$ & $8^{\circ} 10.98^{\prime}$ & 9 & 16.5 & 32.5 & 25 June \\
8 & $54^{\circ} 36.88^{\prime}$ & $7^{\circ} 42.26^{\prime}$ & 17 & 15.7 & 33.3 & 25 June \\
9 & $54^{\circ} 38.44^{\prime}$ & $6^{\circ} 56.41^{\prime}$ & 36 & 14.6 & 35.5 & 26 June \\
10 & $54^{\circ} 28.15^{\prime}$ & $7^{\circ} 15.05^{\prime}$ & 29 & 14.4 & 35.0 & 26 June \\
\hline
\end{tabular}

photometrically (Nusch 1999). For phaeopigment determination, samples were acidified with $\mathrm{HCl}$ $(2 \mathrm{~N})$ prior to spectrophotometric analysis. Bacteria were enumerated by epifluorescence microscopy after staining with 4'-6diamidino-2-phenylindole (DAPI) on black $0.2 \mu \mathrm{m}$ Nuclepore filters at 1000x magnification (Porter \& Feig 1980). For more details on these methods, see Rink et al. (2011).

\section{SPM, POC, chlorophyll and bacterial abundance}

For determination of SPM, filters were dried for $1 \mathrm{~h}$ at $110^{\circ} \mathrm{C}$ and weighed on a micro-balance (Sartorius). POC was determined with a FlashEA 1112 CHN-analyzer (Thermo Finnigan). For chl a analysis, filters were extracted in $90 \%$ ethanol at $75^{\circ} \mathrm{C}$, and concentrations of chl a were determined spectro-

\section{Nucleic acid extraction and quantitative PCR assays for bacterial, SAR11 and RCA 16S rRNA genes}

Genomic DNA was extracted with phenolchloroform as described by Rink et al. (2007) with slight modifications. DNA was precipitated at $-20^{\circ} \mathrm{C}$ overnight using isopropanol and resuspended in 
molecular grade water. Extracted DNA was stored at $-20^{\circ} \mathrm{C}$ until further processing. Amplification and quantitative detection of 16S rRNA gene fragments by qPCR were performed as described by Giebel et al. (2009) with a Rotorgene 3000 thermocycler and followed by data analysis using the Rotorgene software package 6.0 (Corbett Research). Briefly, the PCR reaction with standards and samples was performed in triplicates withdrawn from one sample in a total volume of $25 \mu \mathrm{l}$ in optical grade tubes using the RealMasterMix Probe (5 PRIME, VWR International). Copy numbers of the target genes of the standards were determined from DNA concentrations measured fluorometrically by PicoGreen (Invitrogen) staining and a microplate reader (FLUORstar Optima, BMG) according to the manufacturer's specifications, as well as spectrophotometrically using a Specord 40 instrument (Jena Analytik) with a microcell cuvette (TrayCell, Hellma) and the 260/280 nm ratio (Sambrook et al. 1989). 16S rRNA genes of Bacteria were detected according to Nadkarni et al. (2002) and SAR11-specific 16S rRNA genes according to Suzuki et al. (2001). A plasmid containing the 16S rRNA gene of SAR11 clone MB11M07 (AY033299, provided by M. Suzuki, University of Maryland) was applied as a standard. The design and application of the qPCR assay specific for RCA bacteria is described in detail by Giebel et al. (2009). PCR-generated and -purified 16S rRNA gene fragments of Escherichia coli (ATCC 10798) and a plasmid containing the 16S rRNA gene of an RCA phylotype (RCA-H28) were applied as standards. The 16S rRNA gene of RCA-H28 was amplified from the $10^{-5}$ dilution step of a dilution series of a marine water sample from the Weser estuary, Germany, containing only this phylotype. The average efficiency of the RCA-specific qPCR amplifications was $0.93 \pm 0.03$ (mean $\pm \mathrm{SD}$ ), and the average slope of the standard curve (threshold cycle vs. log of DNA amount) was $-3.5 \pm 0.3$. The detection limit of the RCA-specific qPCR was $0.073 \pm 0.003 \mathrm{fg}$ DNA (corresponding to $39.2 \pm 1.5$ copy numbers), using the clone RCA-H28 as a positive control. We chose $0.3 \mathrm{fg}$ to $120 \mathrm{pg}$ DNA as the apparent amount of target DNA with SD of \pm 0.5 to $\pm 8.8 \%$ in the test runs. Abundances of the RCA and SAR11 groups were determined as the percentage of the total bacterial 16S rRNA genes. The coefficient of variation of triplicate samples was $<10 \%$.

\section{Modeling of the water trajectories}

To reconstruct the water trajectories of the stations visited for the preceding days, a hydrody- namic model of the German Bight (Staneva et al. 2009) was applied. We used a time frame of 24 to $27 \mathrm{~d}$ since 1 June. This period is long enough to follow the development of the plankton community over a certain period, like a bloom, but still allows the tracking of individual water masses. Even though the bulk generation time of bacterioplankton communities is much shorter than this time period, $\sim 1$ to $4 \mathrm{~d}$ (Lemke et al. 2010), this time frame appears more realistic than a shorter period considering mainly the generation time of the specific bacterioplankton used in the present study. The model used is the General Estuarine Ocean Model (GETM; Burchard \& Bolding 2002). It solves the 3-dimensional primitive equations with a free surface on an Arakawa C-grid. Vertically, the model uses 21 terrain following levels. The model consists of a coarse-resolution $(5 \mathrm{~km})$ North SeaBaltic Sea module, a medium-resolution $(0.8 \mathrm{~km})$ module of the German Bight and a high-resolution $(0.2 \mathrm{~km})$ module of the East Frisian Wadden Sea, but we used here only the output of the mediumresolution model. The model is forced by atmospheric fluxes, lateral boundary conditions of sea surface elevation and salinity and hourly river runoff data. The bathymetric data for the different model configurations were prepared using the ETOPO-1 topography (Amante \& Eakins 2009), together with observations made available from the German Hydrographic Service (Bundesamt für Seeschiffahrt und Hydrographie [BSH], Germany; Dick et al. 2001). The sea surface elevations of the open boundary of the North Sea-Baltic Sea model were generated using tidal constituents obtained from the TOPEX/Poseidon data via the OSU Tidal Inversion Software (Egbert \& Erofeeva 2002). Atmospheric fluxes were estimated by the bulk formulation using $6 \mathrm{~h}$ ECMWF re-analysis data. Hourly river run-off data were made available by BSH. More details about the model nesting can be found in Staneva et al. (2009).

Lagrangian particle trajectories of each station were back-tracked using a network common data form (NetCDF, www.unidata.ucar.edu), some implemented modifications and Eulerian backward calculations integrated over the entire depth. For the analyses provided in the results, sea surface temperature (SST) and sea surface salinity (SSS) were extracted from the model output with hourly resolution, and mean values for the back-tracking period were computed. The trajectories were visualized using the Grid Analysis and Display System (GrADS). 


\section{Statistical analysis}

Linear, multiple linear and non-linear regressions were calculated using the statistical software package Sigma Stat 2.03.

\section{RESULTS AND DISCUSSION}

The area of the German Bight visited included 5 shallow near-shore stations (Stns 3-7; Fig. 1B), 4 offshore stations (Stns $1 \& 8-10$ ) and 1 station of intermediate characteristics (Stn 2). The near-shore stations were shallower and had higher temperatures and in most cases lower salinities and higher SPM concentrations relative to the offshore stations; the same distinction was not evident for POC, chl $a$, percentage of phaeopigments and bacterial abundances (Tables $1 \& 2$ ). Stn 2 in the southwestern region was deeper than all of the near-shore stations, but the temperature was as high as at the near-shore stations even though salinity was higher. The phytoplankton was dominated by Rhizosolenia imbricata at all sta-
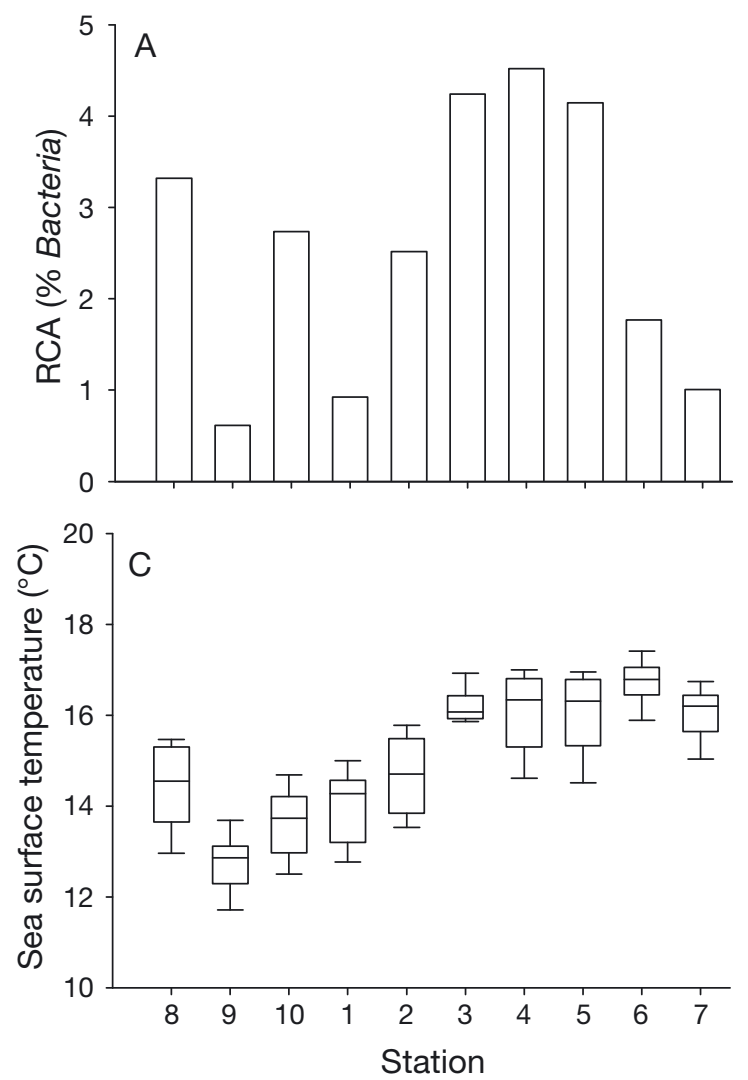

tions, constituting at least $80 \%$ of the cell numbers (Rink et al. 2011). The RCA cluster constituted fractions between $<1$ and $4.5 \%$ of total bacterial $16 \mathrm{~S}$ rRNA genes, with highest fractions at Stns 3 to 5 (Fig. 2A). The SAR11 clade constituted between $<1$ and $47 \%$, with highest fractions of 24 and $47.1 \%$

Table 2. Suspended particulate matter (SPM), particulate organic carbon (POC), chlorophyll $a$, phaeopigments and bacterial abundance at the stations; na: data not available

\begin{tabular}{|c|c|c|c|c|c|}
\hline Station & $\begin{array}{c}\text { SPM } \\
(\mathrm{mg} \\
\left.1^{-1}\right)\end{array}$ & $\begin{array}{c}\text { POC } \\
(\mathrm{mg} \\
\left.1^{-1}\right)\end{array}$ & $\begin{array}{l}\text { Chloro- } \\
\text { phyll a } \\
\left(\mu g 1^{-1}\right)\end{array}$ & $\begin{array}{l}\text { Phaeopig- } \\
\text { ments (\% total } \\
\text { chlorophyll) }\end{array}$ & $\begin{array}{c}\text { Bacteria } \\
\left(10^{6} \mathrm{ml}^{-1}\right)\end{array}$ \\
\hline 1 & 2.0 & 0.21 & 2.7 & 9.10 & 2.4 \\
\hline 2 & 1.4 & 0.14 & 3.7 & 25.2 & 3.2 \\
\hline 3 & 6.8 & 0.44 & 5.0 & 32.8 & 5.1 \\
\hline 4 & 10.8 & 0.38 & 3.0 & 15.7 & 2.4 \\
\hline 5 & 6.5 & 0.16 & 1.5 & 33.9 & 3.8 \\
\hline 6 & 15.4 & 0.78 & 2.3 & 66.2 & 5.5 \\
\hline 7 & 8.4 & 0.42 & 2.7 & 45.4 & 3.7 \\
\hline 8 & 3.7 & na & 6.3 & 3.8 & 2.4 \\
\hline 9 & 2.2 & 0.10 & 1.0 & 52.6 & 1.9 \\
\hline 10 & 2.0 & 0.17 & 3.6 & na & 1.6 \\
\hline
\end{tabular}
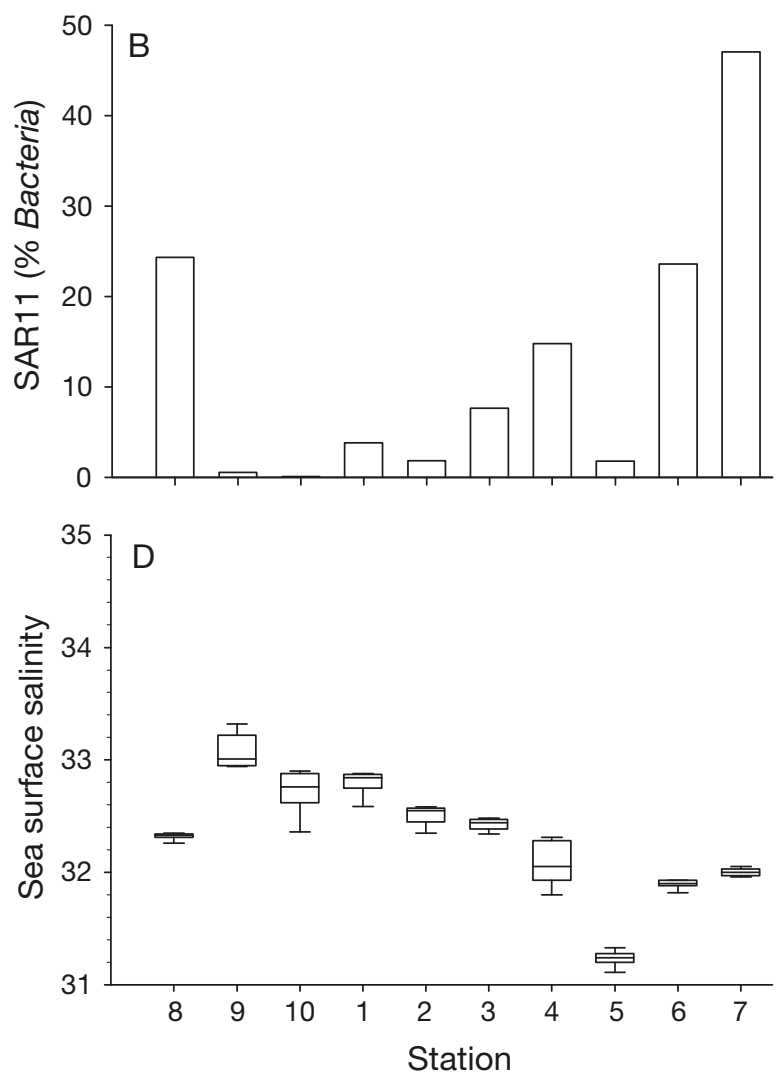

Fig. 2. Abundance of (A) RCA and (B) SAR11 populations (\% of total Bacteria) at the sampling stations in the German Bight in June 2003 and (C,D) box-whisker plots (median; boxes: 25th and 75th percentiles; whiskers: 5th and 95th percentiles) of (C) modeled sea surface temperature and (D) sea surface salinity of the water masses at Stns 1 to 10 in June 2003. The data are based on daily mean values between 1 June and the day of sampling in 2003. Stns 1 and 8 to 10 are offshore stations, and 
at Stns 6 to 8 (Fig. 2B). 16S rRNA genes of both the RCA cluster and the SAR11 clade were only detected in the FL bacterial fraction.

The computed Lagrangian back-trajectories of the various stations exhibited complex current patterns in the German Bight from 1 June until the day of sampling. They are dominated by tidal excursions (spiral-like loops) and depict 3 different transport directions of the northern, central and southern water masses (Fig. 1B). Those of the northern Stns 7 to 10 and of Stn 6 had their origin further north and travelled south in the course of June. Water masses at Stns 1, 2 and 5 had travelled in a westerly direction and those at Stns 3 and 4 eastward. Interestingly, the waters at Stns 4 and 5, which are located closely together, came from opposing directions, and those at Stns 2 and 4 had an origin rather close together. The model yielded a rise in SST at all stations of 3 to $6^{\circ} \mathrm{C}$ from 1 June until the day of sampling irrespective of the given temperature (Fig. 2C). There was no systematic difference in the temperature increment between the off- and on-shore or northern and other stations except that the increment at Stn 3, close to the outlet of a back-barrier tidal flat area (Fig. 1B), was lowest. The initial temperature at this station, however, was higher than at the other stations. The measured in situ temperatures and the modeled SST on the sampling days exhibited a highly significant linear correlation (Fig. 3A; $\mathrm{p}<0.001, \mathrm{r}^{2}=0.86$ ).

In contrast to SST, the SSS of the water masses of the various stations exhibited pronounced differences between 1 June and the sampling day. The greatest variability ( $\triangle \mathrm{SSS}$ ) occurred at Stns 4,9 and 10, whereas at Stns 6 to 8, the SSS remained almost constant (Fig. 2D). The low salinity at Stn 5 reflects that it is located in the plume of the Weser estuary. The measured in situ salinities and the modeled SSS on the sampling day exhibited a highly significant linear correlation (Fig. $3 B_{i} p<0.001, r^{2}=0.85$ ). The increasing difference between the measured and modeled temperature at higher salinity is due to the difference in the salinity modeled for the surface and measured at $3 \mathrm{~m}$ depth by the ship's salinometer. The German Bight exhibits a thin surface layer of a lower and decreasing salinity towards the coast and Wadden Sea overlying a layer with enhanced salinity representing more offshore conditions (Otto et al. 1990).

The relative abundance of the RCA cluster was correlated significantly with bacterial abundance, phaeopigments, chl $a$, POC, SPM and $\triangle$ SSS of the trajectories of the water masses of the stations in a multiple linear regression model, which accounted for $98.1 \%$ of the variability in the RCA data (Table 3). Exclud-
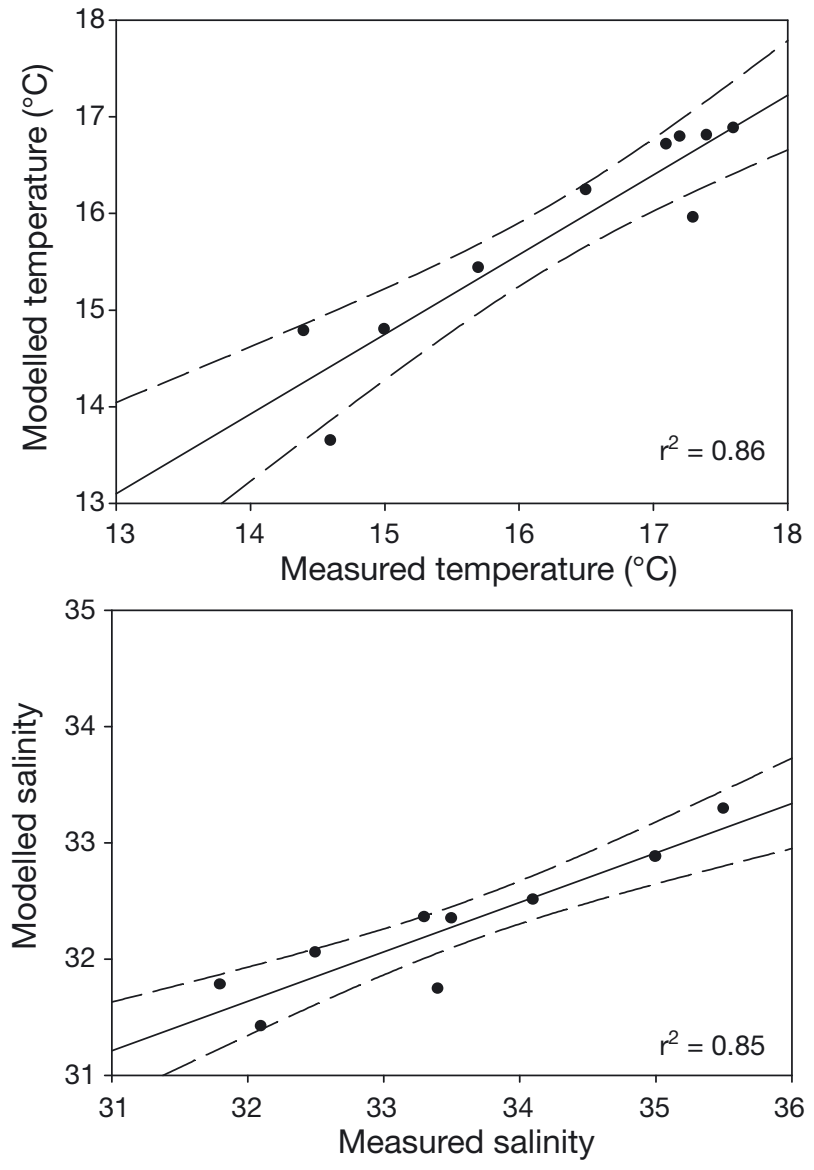

Fig. 3. Linear regression of the measured and modeled (A) temperatures and (B) salinities at the sampling stations on the days of sampling in 2003. Solid line: linear regression, dashed lines: $95 \%$ confidence limits

ing the only non-significant ( $p=0.088$ ) independent variable, phaeopigments, from the regression model, $94.3 \%$ of the variability of the RCA data are still accounted for in this model (Table 3). SPM and POC exhibited collinearity, reflecting the fact that POC is a subfraction of SPM. Temperature yielded a nonsignificant regression component. No single linear, non-linear or other multiple linear regressions with fewer independent variables and the relative abundance of RCA yielded any significant result, presumably reflecting the complex growth requirements of members of this cluster (Giebel et al. 2011). In contrast, the relative abundance of the SAR11 clade exhibited no significant single or multiple linear regression with biogeochemical or environmental variables. However, the relative abundance of the SAR11 clade exhibited a highly significant and inverse non-linear regression with the $\triangle \mathrm{SSS}$ of the trajectories of the water masses of the stations (Fig. 4; 
Table 3. Results of multiple linear regression statistics with the relative abundance of RCA (\%) as the dependent variable and bacterial abundance (bacteria), phaeopigments, chlorophyll $a$, POC, SPM and $\triangle$ SSS as independent variables. $\mathrm{N}=10$. For dimensions of the parameters, see Table 2. VIF: variance inflation factor

\begin{tabular}{|lrrrrc|}
\hline & Coefficient & $\begin{array}{c}\text { Standard } \\
\text { error }\end{array}$ & $t$ & $\mathrm{p}$ & VIF \\
\hline $\mathrm{r}^{2}=0.981$ & & & & & \\
Constant & -5.422 & 1.006 & -5.391 & 0.013 & \\
Bacteria & 0.746 & 0.145 & 5.148 & 0.014 & 2.809 \\
Phaeopigments & 0.028 & 0.011 & 2.499 & 0.088 & 3.55 \\
Chlorophyll a & 1.182 & 0.140 & 8.417 & 0.004 & 3.754 \\
POC & -14.162 & 1.822 & -7.774 & 0.004 & 10.874 \\
SPM & 0.566 & 0.072 & 7.910 & 0.004 & 8.336 \\
$\Delta$ SSS & 4.595 & 0.778 & 5.906 & 0.010 & 2.343 \\
$\mathrm{r}^{2}=0.943$ & & & & & \\
Constant & -3.584 & 1.044 & -3.435 & 0.026 & \\
Bacteria & 0.765 & 0.220 & 3.474 & 0.026 & 2.802 \\
Chlorophyll $a$ & 0.906 & 0.132 & 6.879 & 0.002 & 1.428 \\
POC & -12.444 & 2.565 & -4.851 & 0.008 & 9.325 \\
SPM & 0.519 & 0.105 & 4.944 & 0.008 & 7.754 \\
$\Delta$ SSS & 3.691 & 1.047 & 3.524 & 0.024 & 1.836 \\
\hline
\end{tabular}

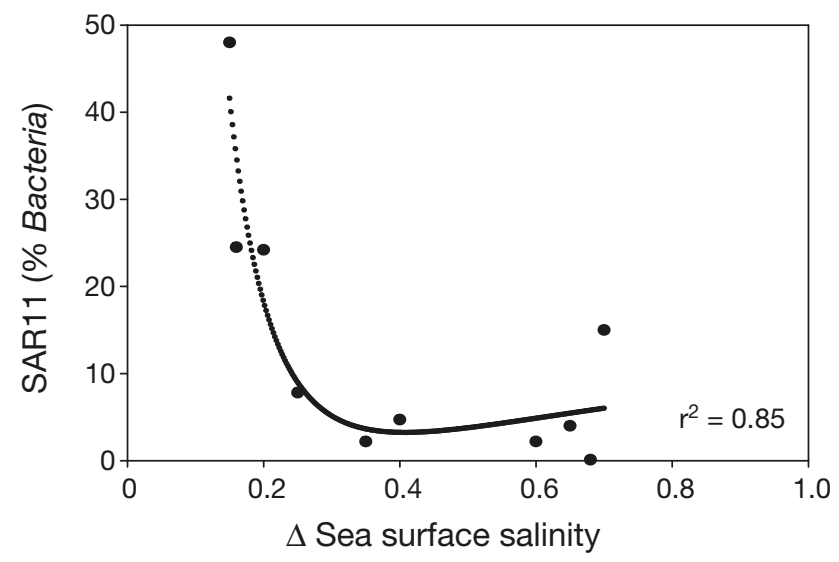

Fig. 4. Non-linear regression of differences (minima and maxima) of the modeled sea surface salinities ( $\triangle \mathrm{SSS}$ ) of the water masses with the abundance of SAR11 at the 10 stations between 1 June and the day of sampling in 2003

$\left.\mathrm{p}<0.01, \mathrm{r}^{2}=0.85\right)$, i.e. the highest abundances occurred at the stations with the most constant salinity and thus the least disturbance and mixing with other waters. In a previous study, pronounced differences between the bacterial community composition of the PA and FL bacterial fractions and of the nearand offshore stations were found (Rink et al. 2011). We did not find these differences for the RCA cluster and the SAR11 clade because both lineages were only detected in the FL bacterial fraction. Rink et al. (2011) reported that differences in the community composition within FL Alphaproteobacteria between the near- and offshore stations were least pronounced, thus supporting our finding. The fact that both phylogenetic lineages were detected only in the FL bacterial fraction is consistent with the study of Giebel et al. (2011) covering the entire North Sea.

The Roseobacter and SAR11 clades are abundant components of the bacterioplankton in the German Bight and the entire North Sea. Previous studies have shown that the SAR11 clade can constitute from $<5$ to $40 \%$ of total bacterial 16S rRNA genes in the North Sea and the RCA cluster from $<2$ to $22 \%$ (Giebel et al. 2011). The SAR11 clade is usually more abundant than the RCA cluster and the entire Roseobacter clade. However, cells of the latter clade are metabolically more active than those of the SAR11 clade, as indicated by the proportions of cells incorporating glucose (Alonso \& Pernthaler 2006). Further, the RCA cluster exhibits many more correlations to environmental and biogeochemical parameters, such as salinity (negative), POC and phaeopigment concentrations, than the SAR11 clade, which appears less responsive to biogeochemical parameters than the RCA cluster (Giebel et al. 2011). Also, the present study showed that the relative abundance of the RCA cluster can be explained by a suite of biogeochemical parameters, whereas that of the SAR 11 clade cannot, underscoring the different controls of both bacterioplankton populations in the southern North Sea. The findings of the present study shed further light on the environmental parameters affecting the abundance of the SAR11 clade in the shallow German Bight of the North Sea by showing that SAR11 accounts for higher proportions of the bacterioplankton only in stable water masses that persist for at least several weeks. Although the growth rates of members of the SAR11 clade are in the same range as those of other planktonic bacteria under optimal conditions (Rappé et al. 2002), net community growth rates of the SAR11 clade have been shown to be lower than those of the Roseobacter clade, Flavobacteria, Sphingobacteria and Gammaproteobacteria in a coastal northwest Spanish upwelling system (Teira et al. 2009). It is conceivable that members of the SAR11 clade, with a relatively small genome (Giovannoni et al. 2005) lacking quite a few regulatory systems and uptake systems for exogenous amino acids and monosaccharides (Tripp et al. 2009, Schwalbach et al. 2010), cannot 
compete with other planktonic bacteria in unstable meso- and eutrophic waters in the same way as in stable water masses. The SAR11 clade consists of several subclusters (Carlson et al. 2009), but our qPCR assay detected only the entire clade. Therefore, we cannot rule out the possibility that this relationship of the SAR11 clade to the stability of water masses is not valid for the entire clade but only for 1 or 2 subclusters. In fact, Carlson et al. (2009) found in the Sargasso Sea that stability and mixing of water masses affected the occurrence of the various subclusters. However, because the hydrography and mixing of the southern North Sea is much more dynamic than in the Sargasso Sea and because all subclusters of the SAR11 clade share a similar small genome with limited substrate uptake systems and regulatory properties, we assume that this relationship is valid for the entire SAR11 clade. Other bacterial lineages, such as Flavobacteria, Sphingobacteria, Gammaproteobacteria and the Roseobacter clade, are obviously better adapted to unstable meso- and eutrophic waters, which often exist in shallow seas like the German Bight, because of their more versatile physiology. We assume that the more stable water masses were more depleted in inorganic nutrients and organic substrates, thus limiting growth of the abovementioned bacterioplankton groups more than that of the SAR 11 clade and providing a competitive advantage to the latter under these conditions, which prevailed at Stns 6, 7 and 8. Ground truth or modeled data and flux rate measurements of inorganic nutrients and organic substrates in the back-tracked water masses may have provided strong support for this assumption. However, such data are not available due to the lack of repeated measurements and missing nutrient models for the German Bight. The significant multiple linear regression of the relative abundance of the RCA cluster with a suite of biogeochemical parameters and $\triangle \mathrm{SSS}$ of the modeled trajectories of the water masses explained at least $94 \%$ of the cluster's variability. However, no single correlation between this cluster and hydrographic parameters, reflecting the currents and stability of these water masses, existed. This result provides strong evidence that growth dynamics of the SAR11 clade and the RCA cluster are controlled differently. In addition to our results, findings by Teira et al. $(2008,2009)$ and by Alonso-Gutiérrez et al. (2009) in an upwelling system along the northwest coast of Spain support this view. These authors found low abundances and net growth rates of the SAR11 clade and dominance of the Roseobacter clade and other bacterioplankton phylogenetic groups in this system.
In studies carried out along upwelling gradients in deeper waters and going beyond the neritic zone, differences in the composition of the bacterioplankton community have been reported (Alonso-Sáez et al. 2007, Baltar et al. 2007, 2010). These differences, however, have been mainly attributed to the nutrient supply and trophic state of the different water masses. The Sphingobacteria, Flavobacteria and Roseobacter clade have been shown to be most responsive to such trophic gradients, with highest proportions in the more eutrophic and upwelling region (Baltar et al. 2007). Suzuki et al. (2001) assessed the horizontal distribution of the bacterioplankton community composition in Monterey Bay of the Californian upwelling system directly at an upwelling event and found that Sphingobacteria and Flavobacteria were directly negatively affected. The SAR11 clade and the Roseobacter clade, with a twofold higher abundance than the SAR11 clade, were less affected, but both lineages exhibited an inverse gradient to the reduced salinity towards the coast.

The role of physical mixing versus biological control for shaping bacterioplankton communities has been investigated specifically only in a study by Hewson et al. (2006). Applying a Lagrangian approach with drifter studies in the Gulf of Mexico, tropical Atlantic and northern central Pacific, these authors found that the composition of bacterioplankton communities was stable over different time periods in these regions, from days to weeks. Modeling the change in stability of the water masses and the bacterioplankton community composition over space and time suggested that mixing contributed to changes in the composition, even though short-term changes due to biological controls also occurred. The southern North Sea is a much more dynamic hydrographic system than the mixed layer of stratified open oceans. Therefore, mixing is a much more important factor in this and similar coastal seas. Because of strong air-sea interactions and dynamic warming by surface irradiation, temperature is not a reliable proxy for water stability in such systems. This is evident from the rise in SST of 3 to $6^{\circ} \mathrm{C}$ in our model from 1 June to the day of sampling and our correlation analysis, which yielded a significant inverse non-linear correlation between the relative abundance of SAR11 and $\Delta$ SSS but not between the former and $\triangle \mathrm{SST}$. Although we do not have direct evidence, we assume that the stations with high $\Delta$ SSS mixing and thus input of substrates favored the more rapidly growing bacterioplankton lineages rather than SAR11. 
Our study shows that a new perspective can be added to understanding the horizontal distribution and dynamics of the relative proportions (and presumably activities) of major bacterioplankton groups by taking into account the preceding history of water masses, i.e. their trajectories. This aspect becomes more important in regions with strong and complex current patterns, such as coastal shallow seas and estuarine systems, but also in regions with strong upwelling activities and dynamic frontal systems. Our analyses have shown that the trajectories of water masses can be reliably backtracked by 2dimensional Lagrangian trajectories. A well suited and fitted 2-dimensional model, supplied with appropriate environmental and hydrographic data, is a prerequisite for such analyses. The close correlation between the modeled and measured salinities and temperatures gives us confidence that the model reliably back-tracked the trajectories of the water masses. The outcome of the analysis also provided important information on the current patterns and the strikingly different trajectories of stations located close together. Such analyses can help in interpreting and understanding differences in the horizontal distribution and community composition of bacterioplankton and other plankton in addition to biogeochemical and environmental parameters. They may also valuably add a Lagrangian aspect to Eulerian studies at fixed stations, such as microbial observatories like the San Pedro Ocean Time Series (SPOTS; Fuhrman et al. 2006), the Bermuda Atlantic Times Series (BATS; Carlson et al. 2009), the Hawaiian Ocean Time Series (HOTS; Karl \& Lukas 1996) and stations in coastal seas, like Helgoland Roads (Wiltshire et al. 2008), which are affected by currents. As shown in the present study, the mixing and stability of water masses is obviously important for the growth or accumulation of abundant populations of distinct bacterioplankton lineages, such as the SAR11 clade.

Acknowledgements. We are most grateful to B. Kuerzel for chl a analyses, to A. Luek for bacterial cell counts and to the crew of the RV 'Heincke' for their excellent cooperation on ship. We also appreciate the constructive comments of 3 reviewers on an earlier version of this manuscript. This work was supported by the Deutsche Forschungsgemeinschaft within the Research Unit BioGeoChemistry of Tidal Flats (FG 432).

\section{LITERATURE CITED}

Alonso C, Pernthaler J (2006) Roseobacter and SAR11 dominate microbial glucose uptake in coastal North Sea waters. Environ Microbiol 8:2022-2030

Alonso-Gutiérrez J, Lekunberri I, Teira E, Gasol JM, Figu- eras A, Novoa B (2009) Bacterioplankton composition of the coastal upwelling system of 'Ría deVigo', NW Spain. FEMS Microbiol Ecol 70:493-505

> Alonso-Sáez L, Arístegui J, Pinhassi J, Gómez-Consarnau I and others (2007) Bacterial assemblage structure and carbon metabolism along a productivity gradient in the NE Atlantic Ocean. Aquat Microb Ecol 46:43-53

Amante C, Eakins BW (2009) ETOPO1 1 Arc-Minute global relief model: procedures, data sources and analysis, Tech Rep, NOAA Technical Memorandum NESDIS NGDC24, Boulder, $\mathrm{CO}$

Baldwin AJ, Moss JA, Pakulski JD, Catala P, Joux F, Jeffrey WH (2005) Microbial diversity in a Pacific Ocean transect from the Arctic to Antarctic circles. Aquat Microb Ecol 41:91-102

Baltar F, Arístegui J, Gasol JM, Hernández-León S, Herndl GJ (2007) Strong coast-ocean and surface-depth gradients in prokaryotic assemblage structure and activity in a coastal transition zone region. Aquat Microb Ecol 50: 63-74

Baltar F, Arístegui J, Gasol JM, Lekunberri I, Herndl GJ (2010) Mesoscale eddies: hotspots of prokaryotic activity and differential community structure in the ocean. ISME J 4:975-988

Becker GA, Dick S, Dippner JW (1992) Hydrography of the German Bight. Mar Ecol Prog Ser 91:9-18

Burchard H, Bolding K (2002) GETM - a general estuarine transport model. Scientific documentation, Tech Rep EUR 20253 EN, European Commission, Ispra

> Carlson CA, Morris R, Parsons R, Treusch AH, Giovannoni SJ, Vergin K (2009) Seasonal dynamics of SAR11 populations in the euphotic and mesopelagic zones of the northwestern Sargasso Sea. ISME J 3:283-295

Crump BC, Armbrust EV, Baross JA (1999) Phylogenetic analysis of particle-attached and free-living bacterial communities in the Columbia River, its estuary and the adjacent coastal ocean. Appl Environ Microbiol 65: 3192-3204

Dick SK, Eckhard K, Müller-Navarra SH, Klein H, Komo H (2001) The operational circulation model of BSH (BSHcmod)-Model description and validation. Jahresber Bundesamt Seeschifffahrt Hydrogr 29:49

> Egbert G, Erofeeva S (2002) Efficient inverse modeling of barotropic ocean tides. J Atmos Ocean Technol 19: 183-204

Fuhrman JA, Hewson I, Schwalbach MS, Steele JA, Brown MV, Naeem S (2006) Annually reoccurring bacterial communities are predictable from ocean conditions. Proc Natl Acad Sci USA 103:13104-13109

> Giebel HA, Brinkhoff T, Zwisler W, Selje N, Simon M (2009) Distribution of Roseobacter RCA and SAR11 lineages and distinct bacterial communities from the subtropics to the Southern Ocean. Environ Microbiol 11: $2164-2178$

> Giebel HA, Kalhoefer D, Lemke A, Thole S, Gahl-Janssen R, Simon M, Brinkhoff T (2011) Distribution of Roseobacter RCA and SAR11 lineages in the North Sea and characteristics of an abundant RCA isolate. ISME J 5:8-19

Giovannoni SJ, Tripp HJ, Givan S, Podar M and others (2005) Genome streamlining in a cosmopolitan oceanic bacterium. Science 309:1242-1245

Hewson I, Fuhrman JA (2004) Richness and diversity of bacterioplankton species along an estuarine gradient in Moreton Bay, Australia. Appl Environ Microbiol 70: 3425-3433 
Hewson I, Steele JA, Capone DG, Fuhrman JA (2006) Temporal and spatial scales of variation in bacterioplankton assemblages of oligotrophic surface waters. Mar Ecol Prog Ser 311:67-77

Karl DM, Lukas R (1996) The Hawaii Ocean Time-series (HOT) program: background, rationale and field implementation. Deep-Sea Res II 43:129-156

Kirchman DL, Dittel AI, Malmstrom RR, Cottrell MT (2005) Biogeography of major bacterial groups in the Delaware estuary. Limnol Oceanogr 50:1697-1706

Lemke A, Lunau M, Badewien TH, Simon M (2010) Shortterm and seasonal dynamics of bacterial biomass production and amino acid turnover in the water column of an intertidal ecosystem, the Wadden Sea. Aquat Microb Ecol 61:205-218

Nadkarni MA, Martin FE, Jacques NA, Hunter N (2002) Determination of bacterial load by real-time PCR using a broad-range (universal) probe and primers set. Microbiology 148:257-266

Nusch EA (1999) Chlorophyllbestimmung. In: von Tuempling W, Friedrich G (eds) Biologische Gewässeruntersuchung. G Fischer, Stuttgart, p 368-375

> Otto L, Zimmermann JTF, Furnes GK, Mork M, Saetre R, Becker G (1990) Review of the physical oceanography of the North Sea. Neth J Sea Res 26:161-238

Pommier T, Pinhassi J, Hagström ^̊ (2005) Biogeographic analysis of ribosomal RNA clusters from marine bacterioplankton. Aquat Microb Ecol 41:79-89

Porter KG, Feig YS (1980) The use of DAPI for identifying and counting the aquatic microflora. Limnol Oceanogr 25:943-948

Rappé MS, Connon SA, Vergin KL, Giovannoni SJ (2002) Cultivation of the ubiquitous SAR11 marine bacterioplankton clade. Nature 418:630-633

Rink B, Seeberger S, Martens T, Duerselen CD, Simon M, Brinkhoff $\mathrm{T}$ (2007) Effects of phytoplankton bloom in a coastal ecosystem on the composition of bacterial communities. Aquat Microb Ecol 48:47-60

Rink B, Grüner N, Brinkhoff T, Ziegelmüller K, Simon M (2011) Regional patterns of bacterial community composition and biogeochemical properties in the southern North Sea. Aquat Microb Ecol 63:207-222

Sambrook J, Fritsch EF, Maniatis T (1989) Molecular

Editorial responsibility: Jed Fuhrman,

Los Angeles, California, USA cloning: a laboratory manual. Cold Spring Harbour Laboratory, New York, NY

Schattenhofer M, Fuchs BM, Amann R, Zubkov MV, Tarran GA, Pernthaler J (2009) Latitudinal distribution of prokaryotic picoplankton populations in the Atlantic Ocean. Environ Microbiol 11:2078-2093

> Schwalbach MS, Tripp HJ, Steindler L, Smith DP, Giovannoni SJ (2010) The presence of the glycolysis operon in SAR11 genomes is positively correlated with ocean productivity. Environ Microbiol 12:490-500

Selje N, Simon M (2003) Composition and dynamics of particle-associated and free-living bacterial communities in the Weser estuary, Germany. Aquat Microb Ecol 30:221-237

Selje N, Simon M, Brinkhoff T (2004) A newly discovered Roseobacter cluster in temperate and polar oceans. Nature 427:445-448

> Staneva J, Stanev EV, Wolff JO, Badewien TH and others (2009) Hydrodynamics and sediment dynamics in the German Bight. A focus on observations and numerical modelling in the East Frisian Wadden Sea. Cont Shelf Res 29:302-319

> Suzuki MT, Preston CM, Chavez FP, DeLong EF (2001) Quantitative mapping of bacterioplankton populations in seawater: field tests across an upwelling plume in Monterey Bay. Aquat Microb Ecol 24:117-127

Teira E, Gasol JM, Aranguren-Gassis M, Fernández A, González J, Lekunberri I, Álvarez-Salgado XA (2008) Linkages between bacterioplankton community composition, heterotrophic carbon cycling and environmental conditions in a highly dynamic coastal ecosystem. Environ Microbiol 10:906-917

Teira E, Martínez-García S, Lønborg C, Álvarez-Salgado XA (2009) Growth rates of different phylogenetic bacterioplankton groups in a coastal upwelling system. Environ Microbiol Rep 1:545-554

Tripp HJ, Schwalbach MS, Meyer MM, Kitner JB, Breaker RR, Giovannoni SJ (2009) Unique glycine-activated riboswitch linked to glycine-serine auxotrophy in SAR11. Environ Microbiol 11:230-238

- Wiltshire KH, Maltzahn AM, Wirtz K, Greve W and others (2008) Resilience of North Sea phytoplankton spring bloom dynamics: an analysis of long-term data at Helgoland Roads. Limnol Oceanogr 53:1294-1302

Submitted: January 9, 2012; Accepted: June 11, 2012

Proofs received from author(s): August 1, 2012 